\title{
4.4 'Rotkäppchen und der Wolfspelz'
}

Peter Rühmkorf's 'Rotkäppchen und der Wolfspelz' is characterised by an intermingling of material from Grimms' version of 'Rotkäppchen' with motifs from other related tales and versions of 'Rotkäppchen', and socio-historical and literary comment and reference, all from within the fictional frame. The text opens with a strong recontextualisation of the opening phrase of 'Rotkäppchen (KHM 26):

Es war einmal eine kleine süße Dirne, ja, mit Apfelbäckchen so richtig zum Anbeißen [... $]^{2}$

This crass sexual allusion contrasts strongly with the scrupulously sanitised Grimmian prose, drawing attention to a pejorative sexual colouration which the word Dirne (=prostitute) has acquired in modern usage, and suggesting a voyeuristic, misogynist element in the appropriated material, which is essentially a depiction of a male wolf (sexually) threatening an innocent young girl. The contrast created also recalls the sexual morality of Perrault's version of the tale, sublimated by the Grimms, as well as Jack Zipes' claim about Perrault's and Grimms' versions of 'Rotkäppchen' that "a male phantasy about how women like to be raped [...] might be at the basis of the narrative itself". ${ }^{3}$ The age of the little girl, a frequent subject of debate amongst psychoanalytic commentators, is

\footnotetext{
1 Peter Rühmkorf: 'Rotkäppchen und der Wolfspelz' in: Der Hüter des Misthaufens: Aufgeklärte Märchen. Reinbek bei Hamburg: Rowohlt 1983, pp. 229-238.

${ }^{2}$ Rühmkorf: 'Rotkäppchen und der Wolfspelz', p. 229.

${ }^{3}$ Zipes: The Brothers Grimm, p. 117.
} 
clearly specified in the text: "Als das Mädchen sechs Jahre alt war [...]", emphasising a pornographic element in the previous sexual allusion. The narrative gives details such as the age and appearance of the little girl, and the location of the Grandmother's house within the first two sentences, in a brisk tone entirely at odds with the abstract narrative style of the Märchen. The little girl's name is revealed as having been determined through the taunting of other children, recalling a version of 'Rotkäppchen' by Max von der Grün where the little girl is persecuted by other children for wearing a red cap. ${ }^{4}$ A strong contrast in 'codes' is thus set up, and reader expectations relating to 'Rotkäppchen' (KHM 26) are evoked. The narrative deliberately reintroduces elements into the plot of the parodic text from oral and literary traditions, revealing the complex origins and heterogeneous sourcing of all versions of the tale and taking issue with the stylistic coherence of Grimms' version of the tale. The Grandmother is given the name "Großmutter Maßschneiderin", ${ }^{5}$ which, in conjunction with the development "Als das Rotkäppchen in die Jahre kam und fast schon so gut mit Nadel, Faden und Schere umgehen konnte wie die Großmutter-Maßschneiderin". echoes Yvonne Verdiers' claim that elements of French oral versions of the tale originated in the initiation of young girls into sewing communities. ${ }^{7}$ In a similar manner, the motif of the little girl as glutton, present in French oral versions of the tale, and the characteristic which defines the tale in the Aarne-Thompson index of folk literature as tale

4 Max von der Grün: 'Rotkäppchen' in: Rotkäppchens Lust und Leid, pp. 178-181.

5 Rühmkorf: 'Rotkäppchen und der Wolfspelz', p. 229.

${ }^{6}$ Rühmkorf: 'Rotkäppchen und der Wolfspelz', p. 230.

${ }^{7}$ Zipes: Rotkäppchens Lust und Leid, p. 21 and n. 15a. 
type AT333, is restored, with the little girl drinking the wine destined for the Grandmother and then attempting to conceal her misdeed. ${ }^{8}$ These and other elements of the conventional plot are altered in sometimes absurd ways, creating multiple levels of comment and comic discrepancy which can be read in terms of the internal consistency of the parodic text, or as highlighting and contrasting with the structure, logic and moral messages of other versions of the tale such as the Grimms' version. For example, the little girl, already depicted as enjoying time spent in the woods to the dismay of her parents, ${ }^{9}$ gives the Wolf directions to Grandmother's house, even making the Wolf carry the gifts, then strolls into the woods to pick flowers of her own accord. ${ }^{10}$ The introduction of this material, and reintroduction of material from other versions of the tale can also be read as functioning, in conjunction with knowledge of 'Rotkäppchen' ( $K H M$ 26), to reveal some of the directions in which the Grimms seem to have modified the tale.

Meanwhile, the preformed material is situated as a Warnmärchen, with the injunction offered by the parents:

Gib nur acht, daß dich dort nicht einmal ein fremder Mann anspricht! [...] Diesen Männern sieht man die Bösigkeit nämlich nicht gleich an der Nase an. ${ }^{11}$

This clear identification of Perrault's cultivated seducer stands in direct contrast to the logical inconsistency of the Grimmian

${ }^{8}$ Rühmkorf: 'Rotkäppchen und der Wolfspelz', pp. 231-232.

9 Rühmkorf: 'Rotkäppchen und der Wolfspelz', p. 230.

${ }^{10}$ Rühmkorf: 'Rotkäppchen und der Wolfspelz', p. 233.

11 Rühmkorf: 'Rotkäppchen und der Wolfspelz', p. 230. 
injunction/transgression/punishment structure. At the same time, the vagueness of the parents' injunction, with its association of 'fremd' and 'Bösigkeit' but corresponding inability to define either of these terms reveals the parents' fears more than it instructs the child, supporting the logical conclusion which the little girl arrives at as a result of the parents' final claim about the appearance of 'fremde Männer':

[...] aber ganz gewiß nicht wie der böse Wolf. «Das ist immerhin was», dachte angeödet das Rotkäppchen, und es nahm sich vor, in Zunkunft auf alle Männer zu achten, die nicht wie der Wolf und der Papa [...] aussahen. ${ }^{12}$

The text permits and even encourages multiple readings; this exchange can be read as social commentary, and, in conjunction with knowledge of the Grimms' text, as comment on the moral structure of 'Rotkäppchen' (KHM 26) or even as criticism of psychological interpretations of 'Rotkäppchen' which make the claim that the narrative is primarily about seduction and rape.

The roles of the central figures in the parodic text can be understood in several ways. The characters are afforded psychological depth, in strong opposition to the Flächenhaftigkeit typical of Grimms' Märchenstil, while it is even suggested that they are aware of their own fictionality and roles within the story:

Komm, laß es genug sein, Rotkäppchen, und uns zu Bett begeben wie es sich gehört. ${ }^{13}$

${ }^{12}$ Rühmkorf: 'Rotkäppchen und der Wolfspelz', p. 231. 
The little girl is portrayed as bold and cunning, in contrast to Grimms' helpless, naive heroine, bantering with the Wolf whilst recognising the element of sexual reference in the danger she faces:

Auch meinte es kinderschlau, daß zu Bett noch lange nicht schlafen heiße $[\ldots]^{14}$

Conversely, the Wolf, who eats the Grandmother's sewing mannequin by mistake and makes no effort to disguise himself as Grandmother, makes clumsy yet direct sexual offers and is portrayed as lacking in intelligence. The behaviour of the characters and portrayal of their personalities can be read as satiric commentary on sexual mores and male-female relationships, as role-reversal and comment with respect to 'Rotkäppchen' (KHM 26), or as criticism of attempts at interpreting 'Rotkäppchen' in this manner.

The text closes with two events which invite symbolic readings. The little girl introduces the Märchen motif of a test in three parts, where the third demand is for the Wolf to remove his pelt. The little girl cuts the pelt off with her pair of sewing scissors and the Wolf is revealed to be "ein bleicher nackter Jüngling". ${ }^{15}$ The Wolf then vomits up the sewing mannequin, and the Grandmother has the last word, in the form of a 'punchline':

«Jaja, das ist ein märchenhafter Stoff, aber sagen Sie, mein Herr, wer hat Ihnen den [Pelz] so saumäßig

\footnotetext{
${ }^{13}$ Rühmkorf: 'Rotkäppchen und der Wolfspelz', p. 236.

${ }^{14}$ Rühmkorf: 'Rotkäppchen und der Wolfspelz', p. 236.

15 Rühmkorf: 'Rotkäppchen und der Wolfspelz', p. 238.
} 
The disrobed 'pale young man' can be understood metaphorically as a disillusioning embodiment of male fantasies about power and control, as the 'core' of the narrative, or as the product of interpretative reduction, while the Grandmother's richly ironic conclusion can be read in the context of the parodic text as a comment on the relationship between the little girl and the Wolf, in relation to 'Rotkäppchen' and reductionist interpretations of the tale, or even as metafictional (selfdeprecating) criticism of the act of writing parody of 'Rotkäppchen'. The parodic text is thus characterised by rich semantic ambivalence, brought about by the conscious alteration of motifs and plot in ways which can be read as revealing moral structures and meanings of 'Rotkäppchen' (KHM 26), or in terms independent of the preformed material. 